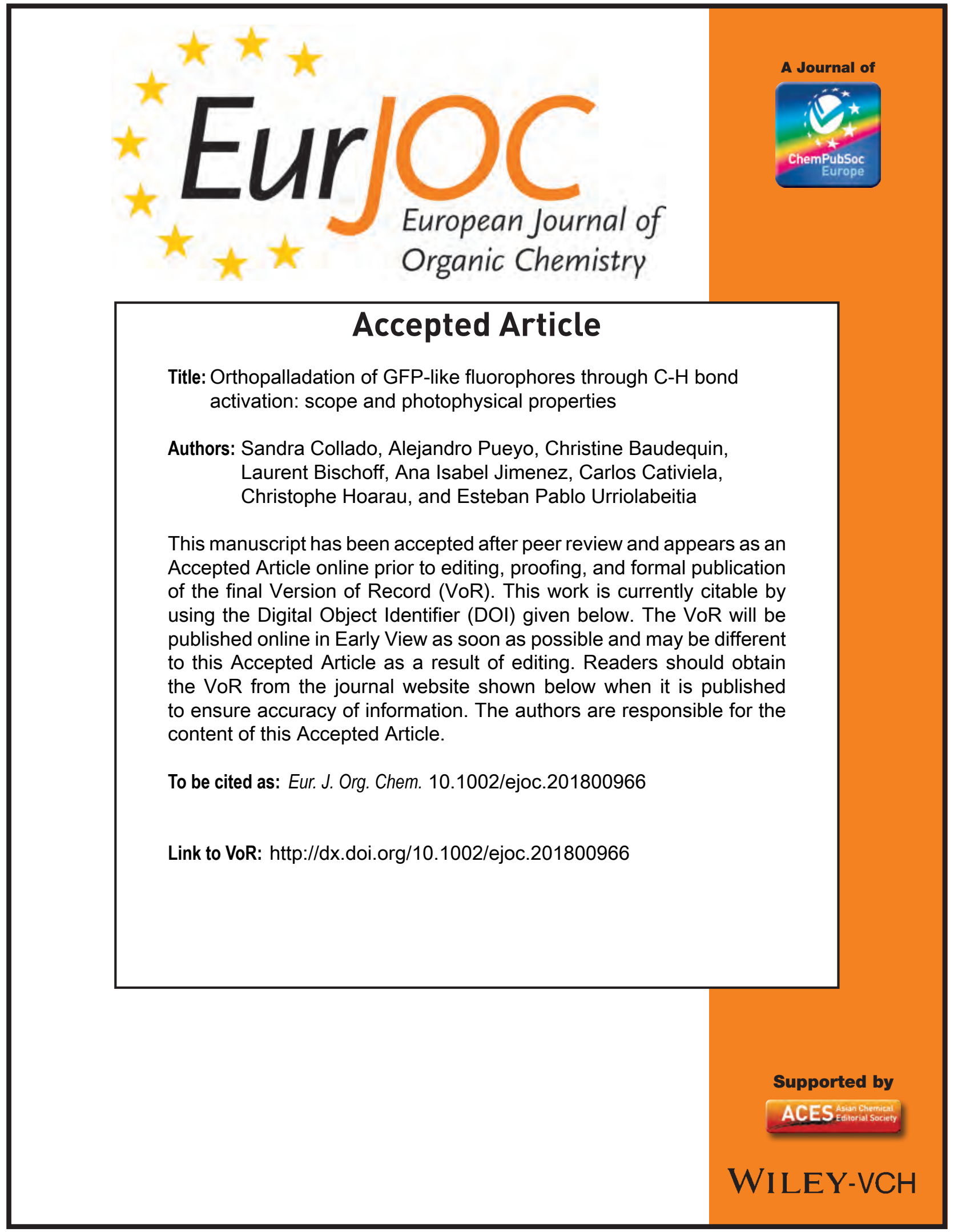


WILEY-VCH

\title{
Orthopalladation of GFP-like fluorophores through C-H bond activation: scope and photophysical properties
}

\author{
Sandra Collado, ${ }^{[a]}$ Alejandro Pueyo, ${ }^{[b]}$ Christine Baudequin, ${ }^{[a]}$ Laurent Bischoff, ${ }^{[a]}$ Ana Isabel Jiménez, ${ }^{[b]}$ \\ Carlos Cativiela, ${ }^{*[b]}$ Christophe Hoarau, ${ }^{*[a]}$ and Esteban P. Urriolabeitia*[b]
}

Dedication ((optional))

\begin{abstract}
The luminescence of oxazolones $\mathrm{R}_{1}-\mathrm{C}_{6} \mathrm{H}_{4} \mathrm{CH}=\mathrm{CC}(\mathrm{O}) \mathrm{O}-$ $\mathrm{CN}\left(\mathrm{R}_{2}\right)(\mathbf{1 a}-\mathbf{1 j})$ and imidazolones $\mathrm{R}_{1}-\mathrm{C}_{6} \mathrm{H}_{4} \mathrm{CH}=\mathrm{CC}(\mathrm{O}) \mathrm{NR} \mathrm{R}_{3} \mathrm{CN}\left(\mathrm{R}_{2}\right)$ (1k1q) has been examined. The new GFP-like imidazolones (GFP = Green Fluorescent Protein) (1k-1q) have been prepared by reaction of the oxazolones with amines $\mathrm{H}_{2} \mathrm{NR}_{3}$ and bis(trimethylsilyl)acetamide. The most intense fluorescence was found in push-pull systems containing simultaneously strong electrondonating and electronwithdrawing substituents. The incorporation of the $\mathrm{Pd}$ atom into the molecular skeleton of oxazolones and imidazolones changes notably their luminescence. The reaction of oxazolones (1a-1j) and imidazolones (1k-1q) with $\mathrm{Pd}(\mathrm{OAc})_{2}(1: 1$ molar ratio) in carboxylic acids gives the dinuclear $\left[\mathrm{Pd}\left(\mathrm{R}_{1}-\mathrm{C}_{6} \mathrm{H}_{3} \mathrm{CH}=\mathrm{CC}(\mathrm{O}) \mathrm{OCN}\left(\mathrm{R}_{2}\right)\right)(\mu-\right.$ carboxylate $)]_{2} \quad(2 \mathrm{a}-2 \mathrm{j})$ and $\left[\mathrm{Pd}\left(\mathrm{R}_{1}-\mathrm{C}_{6} \mathrm{H}_{3} \mathrm{CH}=\mathrm{CC}(\mathrm{O}) \mathrm{NR}_{3} \mathrm{CN}\left(\mathrm{R}_{2}\right)\right)(\mu-\right.$ carboxylate) $]_{2}(\mathbf{2 k - 2 q})$ through regioselective $\mathrm{C}-\mathrm{H}$ bond activation of the ortho position of the respective 4-arylidene rings. Complexes 2a$2 q$ react with $\mathrm{LiCl}$ in $\mathrm{MeOH}$ to give the chloride-bridge derivatives $\left[\mathrm{Pd}\left(\mathrm{R}_{1}-\mathrm{C}_{6} \mathrm{H}_{3} \mathrm{CH}=\mathrm{CC}(\mathrm{O}) \mathrm{OCN}\left(\mathrm{R}_{2}\right)\right)(\mu-\mathrm{Cl})\right]_{2} \quad(\mathbf{3 a}-\mathbf{3} \mathbf{j})$ and $\left[\mathrm{Pd}\left(\mathrm{R}_{1-}\right.\right.$ $\left.\left.\mathrm{C}_{6} \mathrm{H}_{3} \mathrm{CH}=\mathrm{CC}(\mathrm{O}) \mathrm{NR}_{3} \mathrm{CN}\left(\mathrm{R}_{2}\right)\right)(\mu-\mathrm{Cl})\right]_{2}$ (3k-3q), which further react with $\mathrm{TI}(\mathrm{acac})($ acac $=$ acetylacetonate) to give the mononuclear species $\left[\mathrm{Pd}\left(\mathrm{R}_{1}-\mathrm{C}_{6} \mathrm{H}_{3} \mathrm{CH}=\mathrm{CC}(\mathrm{O}) \mathrm{OCN}\left(\mathrm{R}_{2}\right)(\mathrm{acac})\right] \quad(\mathbf{4 a}-\mathbf{4 j}) \quad\right.$ and $\quad\left[\mathrm{Pd}\left(\mathrm{R}_{1-}\right.\right.$ $\left.\mathrm{C}_{6} \mathrm{H}_{3} \mathrm{CH}=\mathrm{CC}(\mathrm{O}) \mathrm{NR}_{3} \mathrm{CN}\left(\mathrm{R}_{2}\right)(\mathrm{acac})\right]$ (4k-4q). Complexes $\mathbf{4 0}$ and $\mathbf{4 q}$, having an orthopalladated push-pull imidazolone, are strongly fluorescent, showing a notable increase of the quantum yield with respect to the free ligands $\mathbf{1 0}$ and $\mathbf{1 q}$ up of one order of magnitude.
\end{abstract}

\section{Introduction}

The synthesis of compounds with photophysical properties of interest (fluorescence, phosphorescence) is a research area undergoing an increasing development due to their potential applications and impact in our daily life. We find outstanding applications of these compounds in optical devices and in the

[a] S. Collado, Dr. C. Baudequin, Prof. Dr. L. Bischoff, Prof. Dr. C. Hoarau

Normandie Univ, UNIROUEN, INSA Rouen, CNRS, COBRA, 76000 Rouen, France

1 rue Tesnière, 76821 Mont Saint Aignan, France

E-mail: christophe.hoarau@insa-rouen.fr

[b] A. Pueyo, Dr. A. I. Jiménez, Prof. Dr. C. Cativiela, Dr. E. P. Urriolabeitia

Instituto de Síntesis Quimica y Catálisis Homogénea (ISQCH)

CSIC-Universidad de Zaragoza

Pedro Cerbuna 12, 50009 Zaragoza, Spain

webpage: www.isqch.unizar-csic.es/ISQCHportal/grupos.do?id=38

E-mail: esteban@unizar.es, cativiela@unizar.es

Supporting information for this article is given via a link at the end of the document. diagnosis of many diseases, detected using fluorescent probes or biological markers. ${ }^{[1-7]}$ Despite the progress achieved in this area, there are not large libraries of synthetic compounds that could be used on the mentioned purposes, and continuous research is needed. Sometimes, the nature provides bright solutions, and many natural compounds display luminescent properties. Among them, GFP (Green Fluorescent Protein), and their mutations or derivatives, offer very interesting possibilities. ${ }^{[8-21]}$

GFP is a protein that shows an intense and bright green emission when it is irradiated with UV light. It shows widespread use in scientific research, because it allows to see what happens into the inner workings of cells, how the proteins are being made, and even any movement of the proteins. ${ }^{[8-21]}$ The way it works is extremely simple, because it is just necessary to attach the GFP to the target object (i.e., a virus): as the virus replicates and disseminates, it is possible to see it just turning on the UV light and watching the green glow. Due to all these facts it has been named the microscope of the twenty-first century. The utility of the GFP and its derivatives has been recognized with the chemistry Nobel prize in 2008, that was awarded to Profs. Shimomura Chalfie and Tsien. ${ }^{[16-18]}$

However, the true responsible of the photophysical activity of the GFP, the chromophore, is a small heterocyclic unit present in the inner part of the protein, the 4-( $p$-hydroxybenzylidene)-5-(4H)imidazolone (Figure 1a), which is formed from residues of the amino acids serine (Ser65), tyrosine (Tyr66) and glycine (Gly67), although other combinations are also possible depending of the type of GFP. ${ }^{[22,23]}$<smiles>[R]C1=N/C(=C\c2ccc([R])cc2)C(=O)N1[R3]</smiles>

(a) Imidazolone<smiles>[R]C1=N/C(=C\c2ccc([R])cc2)C(=O)O1</smiles>

(b) Oxazolone
Figure 1. General structure of (a) the chromophore of GFP (Imidazolone) and (b) its synthetic precursor (oxazolone)

This fact helps the synthetic chemists in the task of the development of more efficient fluorophores, because it is substantially easier the tuning of the heterocyclic core responsible of the fluorescence (the imidazolone) than that of the whole protein (GFP). In this respect, we have recently developed the synthesis of a variety of 4-aryliden-2-alkenyl-imidazolones and 4aryliden-2-aryl-imidazolones through $\mathrm{C}-\mathrm{H}$ bond alkenylation and/or arylation of corresponding $2-H$ derivatives, ${ }^{[24,25]}$ and also 
through direct reaction of the precursor oxazolones with amines followed by cyclizative dehydration using bis(trimethylsilyl)acetamide. ${ }^{[26]}$ Therefore, the synthetic access to a large library of different imidazolones and oxazolones ${ }^{[27-44]}$ is available. On the other hand, imidazolones and their parent oxazolones show notable photophysical properties, which are of high interest. For instance, oxazolones are able to perform two-photons absorption (TPA), ${ }^{[45-47]}$ they interact with the light through $Z-E$ isomerization processes, ${ }^{[48-51]}$ and are able to give [2+2]-photocycloaddition reactions. ${ }^{[52-54]}$ In addition, detailed studies have been devoted to the improvement of the quantum yield of the luminescence of imidazolones through rigidification, aiming to suppress as much as possible the thermal deactivation pathways associated to different internal rotations (hula-twist). ${ }^{[55-60]}$ In this respect, the introduction of a $\mathrm{BF}_{2}$ group in the molecular skeleton of the imidazolones through $\mathrm{N}-\mathrm{H}^{[61]}$ or $\mathrm{C}-\mathrm{H}^{[62-66]}$ bond activation (Figure 2, left part) has shown to give rigid highly fluorescent compounds, because radiationless decay has been minimized efficiently. Thus, rigidification connecting both rings (arylidene and heterocycle) seems to be an adequate tool to improve the photophysical properties of these molecules.
Surprisingly, the use of transition metals for rigidification of imidazolones has never been attempted and, in the case of oxazolones, only some few cases using $\mathrm{Pd}$ as metal have been reported. ${ }^{[53,79-82]}$ Moreover, the photophysical properties of the oxazolones once cyclopalladated remains totally unexplored. Due to all of the abovementioned reasons, we have carried out a systematic study of the orthopalladation through $\mathrm{C}-\mathrm{H}$ bond activation of different 2-aryl-4-aryliden-5(4H)-imidazolones and 4aryliden-5(4H)-oxazolones, and their luminescence studies. In this contribution we present the obtained results.

\section{Results and Discussion}

1.- Synthesis of the precursors. We have selected a large variety of oxazolones and imidazolones to screen different possibilities (Chart 1).

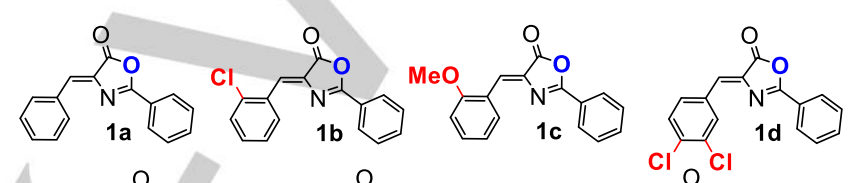

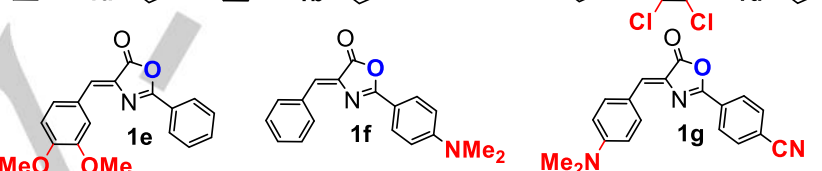
$\mathrm{MeO} \mathrm{OMe}$<smiles>COc1ccccc1CC(=O)OCC(C)C</smiles><smiles>C=C(C)N(C)C(=O)Cc1ccc(OC)cc1</smiles>

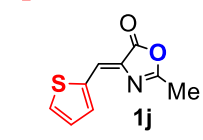<smiles></smiles><smiles></smiles>

Previous work: boron

$\mathbf{R}_{1}, \mathbf{R}_{2}, \mathbf{R}_{3}$ : ligand tuning

Burgess $^{[61]}$ and Yampolsky ${ }^{[62]}$
Rigid structures

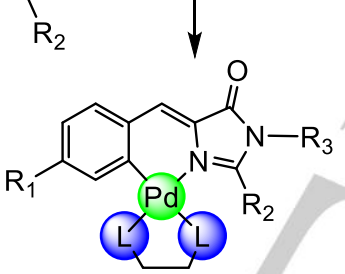

This work: palladium

Rigid structures

Additional tuning:

- Pd

- ancillary ligands
Figure 2.General structure of (a) the chromophore of GFP (Imidazolone) and (b) its synthetic precursor (oxazolone)

Following in this line, $B$ is not the only atom able to be incorporated to the oxazolone or imidazolone scaffolds. In particular, the incorporation of transition metals forming $\mathrm{C}, \mathrm{N}-$ cyclometallated derivatives in highly advantageous due to several reasons (Figure 2, right part). ${ }^{[67-75]}$ This type of ligands provides exceptional thermodynamic stability to the resulting complexes and modifies the molecular orbital distribution, deactivating nonradiative transitions centered in the metal orbitals. In addition, this allows the harvesting of triplet states, this being highly desirable when dealing with OLEDs applications. ${ }^{[6]}$ At the same time, it provides high rigidity to the metal-ligand environment, this also quenching other non-radiative energy dissipation pathways, as expected from our previous discussion. ${ }^{[7]}$ The resulting molecule can additionally be tuned through change of the ancillary ligands. For all those reasons, cyclometallated derivatives are exceptional candidates in the development of efficient luminescent systems. Among different methods to make cyclometallated derivatives, the $\mathrm{C}-\mathrm{H}$ bond activation is a well-known synthetic tool. ${ }^{[78]}$
We have selected examples of oxazolones (1a-1j) containing one or two substituents of electron-withdrawing or electron-donating nature, located at different positions of the 4-arylidene ring to cover all possibilities to tune the electron density and the steric hindrance. We have also selected examples having an aryl group (1a-1g) or a methyl group (1h-1j) at 2-position, aiming to change the degree of delocalization of the electron density and the bulkiness of the whole ligand. In the case of imidazolones we have followed the same criteria in a reduced number of examples (1k-1q), because we have focused in the push-pull systems (101q), those having a strong electron-releasing group at the 4arylidene ring and a strong electron-withdrawing group at the 2position of the imidazolone. The choice of the $n$-propyl group as substituent for the $\mathrm{N}$ atom is due to their chemical inertness and its role as ${ }^{1} \mathrm{H}$ NMR probe (see below). The synthesis of the oxazolones 1a-1j has been performed following basically the Erlenmeyer method, ${ }^{[27-44]}$ heating the hippuric or the aceturic acid with $\mathrm{NaOAc}$ and with the corresponding aldehyde, using acetic 
WILEY-VCH

anhydride as reaction solvent. On the other hand, the synthesis of the imidazolones $\mathbf{1 k - 1 q}$ has also been carried out by adaptation of known procedures previously published by some of us. ${ }^{[24-26]}$ The reaction takes place in two steps from oxazolone precursors. In the first step the oxazolone reacts with the amine opening the heterocycle and giving the bis-amide derivative, which in the second step undergoes dehydration by reaction with bis(trimethylsilyl)-acetamide and ring closure (Figure 3).

a)<smiles>[R]C(=O)NCC(=O)N[N+](=O)[O-]</smiles>

$\mathrm{R}_{2}=\mathrm{Ph} ; \mathrm{R}_{1}=\mathrm{H}(\mathbf{1} \mathbf{a}), 2-\mathrm{Cl}(\mathbf{1 b}), 2-\mathrm{OMe}(\mathbf{1 c}), 3,4-\mathrm{Cl}_{2}(\mathbf{1 d}), 3,4-(\mathrm{OMe})_{2}(\mathbf{1 e})$ $\mathrm{R}_{2}=\mathrm{C}_{6} \mathrm{H}_{4} \mathrm{NMe}_{2}, \mathrm{R}_{1}=\mathrm{H}$ (1f).

$\mathrm{R}_{2}=\mathrm{C}_{6} \mathrm{H}_{4} \mathrm{CN}, \mathrm{R}_{1}=\mathrm{C}_{6} \mathrm{H}_{4} \mathrm{NMe}_{2}(\mathbf{1 g})$

$R_{2}=M e ; R_{1}=2-O M e(1 h), 3,4-(O M e)_{2}$ (1i), 2-thienyl (1j)

b)

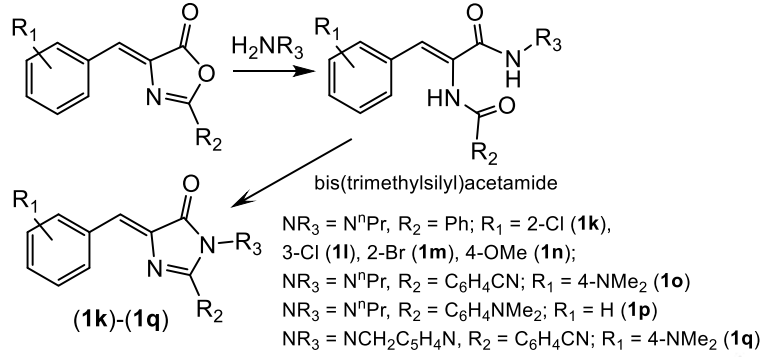

Figure 3. Synthetic pathways for the preparation of oxazolones $\mathbf{1 a - 1 j}$ and imidazolones $\mathbf{1 k - 1 q}$

2.- Orthopalladation of oxazolones and imidazolones. The orthopalladation of (Z)-2-aryl-4-aryliden-5(4H)-oxazolones has been reported by us some years ago, and these are up to date the only reports about palladation through $\mathrm{C}-\mathrm{H}$ bond activation on oxazolones. ${ }^{[53,79-81]}$ Despite its apparent simplicity, the reaction shows some peculiarities. It takes place only in carboxylic acids as solvents, which participate actively during the reaction mechanism. In addition, the type of oxazolones to be activated strongly depends of the $\mathrm{pK}_{\mathrm{a}}$ of the acid, in such a way that in weak acids (for instance acetic acid) only very electron-rich substrates undergo $\mathrm{C}-\mathrm{H}$ bond activation, while in strong acids (trifluoroacetic acid) even highly deactivated electron-deficient rings undergo C$\mathrm{H}$ bond activation. ${ }^{[53,80]}$ Under these conditions, it is observed that the palladation 2-aryl-4-aryliden-5(4H)-oxazolones is totally regioselective towards the activation of the ortho $\mathrm{C}-\mathrm{H}$ bond of the 4-arylidene ring, giving a six-membered ring palladacycle. Aiming to check if these observations are general, we have attempted the palladation of 2-methyl-4-aryliden-5(4H)-oxazolones (1h-1j) and 2-aryl-4-aryliden-5(4H)-imidazolones (1k-1q), shown in Figure 4. We initially tried the orthopalladation of 2-methyl oxazolones $1 \mathrm{~h}$ 1j under the same reaction conditions as those reported for 2phenyl derivatives $\mathbf{1 a - 1 g}\left(\mathrm{CF}_{3} \mathrm{COOH}, 25\right.$ to $\left.75^{\circ} \mathrm{C}\right)$. The reaction failed in all attempted cases, because extensive decomposition was observed even at room temperature, and no definite compounds could be isolated at the end of the reaction. Supposing that this could be due to the strength of the acid, we carried out the reactions in the weaker acetic acid as solvent at different temperatures. The reaction at the reflux temperature was successful for the three oxazolones, and the corresponding dinuclear derivatives $\mathbf{2} \mathbf{h}-\mathbf{2} \mathbf{j}$ were obtained in moderated to quantitative yields (see ESI for details). Probably, the reason of the higher reactivity of 2-methyl-oxazolones $\mathbf{1 h}-\mathbf{1 j}$ compared with the 2-phenyl counterparts is due to the higher electron density in the aromatic ring in the former substrates. The characterization of 2h-2j shows that the palladation has taken place with full regioselectivity at the ortho $\mathrm{C}-\mathrm{H}$ bond of the 4-arylidene ring $(2 \mathrm{~h}$, $2 \mathrm{i}$ ) or at the 3-position of the 2-thiophene ring $(2 \mathrm{j})$, acting the $\mathrm{N}$ atom of the oxazolone ring as directing group. In the case of $\mathbf{2 i}$ two isomers are possible in principle, but only the less hindered one is obtained, because Pd incorporation is produced at the 6position of the starting oxazolone 1i. The dinuclear nature of these derivatives is inferred from the observation of a strong peak in the mass spectrum of $\mathbf{2 h}$ (positive ESI) at 738.8475 a.m.u., which agrees with the presence of the dimer $\left[\mathrm{Pd}\left(\mathrm{C}^{\wedge} \mathrm{N}\right)\left(\mathrm{O}_{2} \mathrm{CCH}_{3}\right)\right]_{2}$ which has captured a $\mathrm{Na}^{+}$cation. Taking into account the dinuclear nature of $\mathbf{2 h - 2 j}$, the observation of a single peak for the methyl group of the bridging acetate strongly suggests that the relative arrangement of the two cyclopalladated units $\left[\operatorname{Pd}\left(C^{\wedge} N\right)\right]$ is anti, minimizing the steric interactions between the two palladium environments. All these facts are reflected in the proposed structures shown in Figure 4.
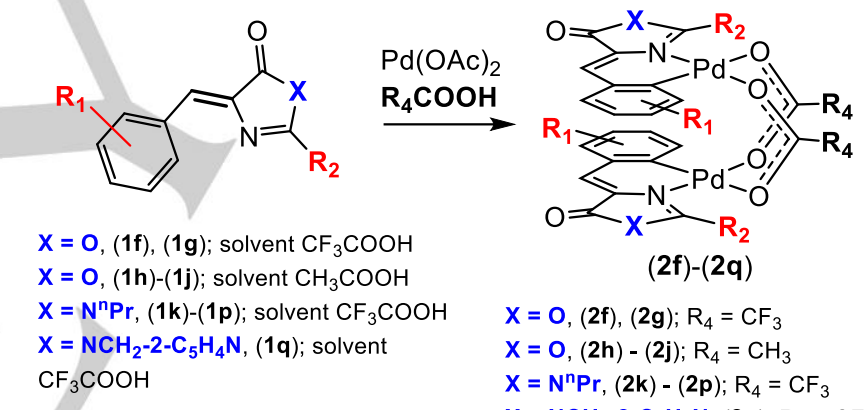

(2f)-(2q)

$\mathrm{X}=\mathbf{0},(\mathbf{2 f}),(\mathbf{2 g}) ; \mathrm{R}_{4}=\mathrm{CF}_{3}$ $\mathbf{X}=\mathbf{O},(\mathbf{2 h})-(\mathbf{2 j}) ; \mathrm{R}_{4}=\mathrm{CH}_{3}$ $\mathbf{X}=\mathbf{N}^{\mathrm{n}} \mathrm{Pr},(\mathbf{2 k})-(\mathbf{2 p}) ; \mathrm{R}_{4}=\mathrm{CF}_{3}$ $X=\mathrm{NCH}_{2}-2-\mathrm{C}_{5} \mathrm{H}_{4} \mathrm{~N},(2 \mathrm{q}) ; \mathrm{R}_{4}=\mathrm{CF}_{3}$

Figure 4. Orthopalladation of diverse oxazolones and imidazolones

On the other hand, the orthopalladation of 2-phenyl-4-aryliden$5(4 H)$-imidazolones $\mathbf{1 k - 1 q}$ (Chart 1) takes place under experimental conditions similar to those reported for the parent oxazolones. ${ }^{[80]}$ That is, the mixture of the imidazolone and $\mathrm{Pd}(\mathrm{OAc})_{2} \quad\left(1: 1\right.$ molar ratio) has to be heated at $75{ }^{\circ} \mathrm{C}$ in trifluoroacetic acid as solvent for $4 \mathrm{~h}$ to promote the reaction. Under these conditions, the dimers $\mathbf{2 k - 2 q}$ are formed in moderate to excellent yields (57-99\%), as it is shown in Figure 4. Indeed, the characterization of $\mathbf{2 k} \mathbf{k}-\mathbf{2 q}$ shows that the reaction occurs with strictly the same regioselectivity than that observed previously in oxazolones $^{[80]}$ or in complexes $\mathbf{2 f - 2} \mathbf{j}$, and that only the 4-arylidene ring has been palladated, despite the presence of other potential directing groups, such as the pyridine fragment in 1q. In addition, $\mathbf{2 k - 2 q}$ are dinuclear as well, with a relative anti arrangement of the cyclopalladated moieties, as it can be deduced from the diastereotopic character of the $\mathrm{NCH}_{2}$ protons in the respective ${ }^{1} \mathrm{H}$ NMR spectra, and from the observation of a single peak in the ${ }^{19} \mathrm{~F}$ NMR spectra (meaning chemically equivalent bridging $\mathrm{CF}_{3}$ groups, see ESI). From the observed reactivity of oxazolones 1f1j and imidazolones $\mathbf{1 k - 1 q}$, we can conclude that the selectivity 
observed in the cyclopalladation of 4-aryliden-5(4H)-oxazolones and 4-aryliden-5(4H)-imidazolones is the same, and that the process is general.

3.- Synthesis of the acetylacetonate derivatives. Even if the dinuclear complexes $\mathbf{2 a - 2 q}$ could be potential candidates for the study of their luminescent properties, it is clear that they are not the best examples, due to several reasons. The main one is the flexibility exhibited by these dimers in solution and, hence, the concomitant loss of energy through non-radiative pathways. Therefore, it is proposed the change of the bridging acetate dimers in $\mathbf{2 a - 2 q}$ by other ligands aiming to obtain more rigid systems. The acetylacetonate (acac) is the ideal candidate to achieve this task, because it behaves as a strong chelate to the $\mathrm{Pd}$, providing additional stabilization to the resulting complexes, and confers them good solubility properties. Moreover, acaccomplexes are often found in complexes with excellent optical capabilities. $^{[83-85]}$ The synthesis of the corresponding acacderivatives was accomplished following standard methods, as outlined in Figure 5. Briefly, the dimers with bridging carboxylate ligands $\mathbf{2 a - 2 q}$ were reacted with excess of $\mathrm{LiCl}$ (1:4 molar ratio, or higher) in $\mathrm{MeOH}$, giving the corresponding planar dimers with bridging chloride ligands $\mathbf{3 a - 3 q}$, through a metathesis of anionic ligands. Complexes $\mathbf{3 a - 3 q}$ are very insoluble in $\mathrm{MeOH}$, and can be isolated by simple filtration. Further reactivity of $\mathbf{3 a - 3 q}$ with either Tlacac (1:2 molar ratio) in $\mathrm{CH}_{2} \mathrm{Cl}_{2}$, or with potassium acetylacetonate (1:2 molar ratio) in $\mathrm{MeOH}$, gives the acacderivatives $\mathbf{4 a - 4 q}$ as yellow or red solids in moderate to very good yields. They are adequately soluble in the usual organic solvents and are stable for months when exposed to the air and the moisture. The characterization of $\mathbf{4 a - 4} \mathbf{q}$ has been carried out following usual methods (HRMS, NMR) and is straightforward.

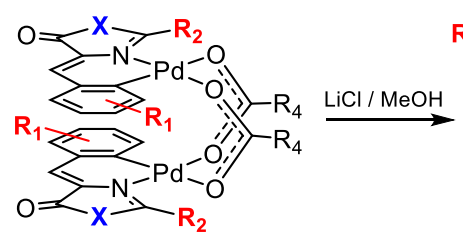

(2a)-(2o)

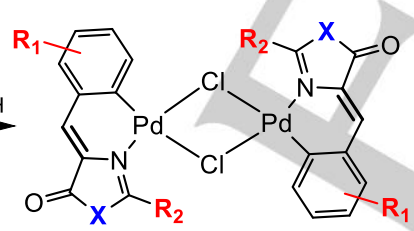

(3a)-(3o)

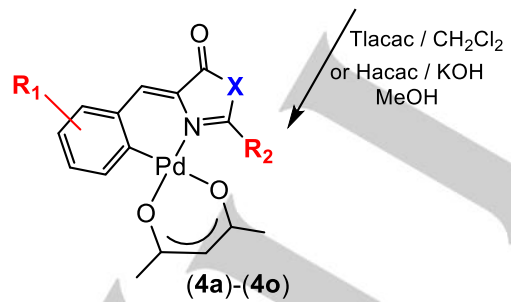

Figure $\mathbf{5}$. Synthesis pathway to the acetylacetonate complexes $\mathbf{4 a - 4 q}$

\section{4.- Photophysical properties of orthopalladated oxazolone} and imidazolone complexes. The optical properties of the 4arylidene oxazolones and imidazolones and their orthopalladated analogs were recorded in $\mathrm{CH}_{2} \mathrm{Cl}_{2}$ at $25{ }^{\circ} \mathrm{C}$ by UV/Vis and photoluminescence (PL) spectroscopy. The data of the fluorescent compounds are summarized in Tables 1 and 2 . Unfortunately, the 4-arylidene oxazolones (1a-1e and $\mathbf{1 h - 1 j}$ ) and their corresponding orthopalladated compounds are not fluorescent. Concerning the oxazolones (1f-1g) and the imidazolones (10-1q), they have absorption wavelengths $\left(\lambda_{\text {abs }}\right)$ in the purple to blue region. As expected, only push-pull systems offering an important charge transfer permit to obtain interesting photophysical properties both for oxazolones and imidazolones. The first possibility consists to introduce the dimethylamino (electron-donating group) in para-position on the arylidene ring and the cyano group (electron-withdrawing part) on the C2 position on the oxazolone (1 $\mathbf{g}$ ) or the imidazolone core (10 or 1q). A similar system but in the opposite site have been elaborated, the 4-(dimethylaminp) phenyl was introduced on the $\mathrm{C} 2$ site and the oxazolone or the imidazolone can be considered as the electron-withdrawing part (1f and 1p).

We have already observed that the replacement of the dimethylamino by a methoxy group, less electron-donor than dialkylamino, resulted in decreased photophysical properties, notably the quantum yield. As previously reported by Rodrigues et $a l,{ }^{[46]}$ the better quantum yield concerning the oxazolone series was obtained when the dimethylaniline is introduced at the C2 position. The comparison of compounds $\mathbf{1 g}, \mathbf{1 0}$ and $\mathbf{1 q}$ that have the 4-cyanophenyl and 4-(dimethylamino)phenyl groups as external substituents allows to evaluate the influence of the core. The incorporation of an imidazolone core instead of an oxazolone led to a blueshift of the absorption maxima $\left(\lambda_{\text {abs }}\right)$ and emission $\left(\lambda_{\mathrm{em}}\right)$, a decrease of the molar extinction coefficient $(\varepsilon)$ and similar quantum yield. When the oxazolones were orthopalladated, similar values for the absorption and the emission wavelengths ( \pm $10 \mathrm{~nm}$ ) were observed, however we noticed an important decrease for both the quantum yield (1f vs 4f, 0.591 vs 0.018 ) and the molar extinction coefficient $\varepsilon$ (55223 vs 19195 and 53534 vs 8024). The comparison between the push-pull imidazolones (Table 1, $\mathbf{1 0}$ and 1q) and their orthopalladated analogs (Table 2, $\mathbf{4 0}$ and $\mathbf{4 q}$ ) reveals a decrease of the molar extinction coefficient $(\varepsilon)$, but an important redshift for both absorption and emission maxima as well as an important increase of the quantum yield (4.2 and $1 \%$ vs 0.3 and $0.2 \%$ ) are observed. Concerning compound 1p encompassing EWG and EDG at inverted positions compared to classical fluorescent molecules of this family, i.e. "inverted push-pull", incorporating the 4-dimethylaminophenyl on the C2 ring and in this case, the imidazolone can be considered as the electron-withdrawing part, the fluorescence is turned-off upon ortho-palladation.

Table 1. Photophysical data for 4-arylidene oxazolones and imidazolones in dichloromethane at $25^{\circ} \mathrm{C}$.

\begin{tabular}{cccccc}
\hline Compound $^{[\mathrm{a}]}$ & $\begin{array}{c}\lambda_{\mathrm{abs}, \max } \\
{[\mathrm{nm}]}\end{array}$ & $\begin{array}{c}\varepsilon \\
{\left[\mathrm{M}^{-1} \mathrm{~cm}^{-1}\right]}\end{array}$ & $\begin{array}{c}\lambda_{\mathrm{em}, \max } \\
{[\mathrm{nm}]}\end{array}$ & $\Phi_{\mathrm{F}}^{[\mathrm{b}]}$ & $\begin{array}{c}\text { Stokes } \\
\text { shift }\left[\mathrm{cm}^{-1}\right]\end{array}$ \\
\hline 1f & 436 & 55223 & 518 & $0.59^{[\mathrm{c}]}$ & 3630 \\
1g & 496 & 53534 & 550 & $0.008^{[\mathrm{d}]}$ & 1979 \\
10 & 473 & 46742 & 562 & $0.003^{[\mathrm{c}]}$ & 3348 \\
1p & 422 & 15572 & 505 & $0.054^{[\mathrm{d}]}$ & 3895 \\
1q & 478 & 43942 & 592 & $0.002^{[\mathrm{c}]}$ & 4028 \\
\hline
\end{tabular}

[a] All spectra were recorded at $25^{\circ} \mathrm{C}$. [b] Quantum yield $( \pm 10 \%)$ of fluorescence determined by using : [c] Coumarine-153 $\left(\Phi_{\mathrm{F}}=0.38\right.$ in $\mathrm{EtOH}$, $\lambda_{\text {exc }}=430$ or $\left.450 \mathrm{~nm}\right)$; or [d] Rhodamine $6 \mathrm{G}\left(\Phi_{\mathrm{F}}=0.94\right.$ in $\mathrm{EtOH}, \lambda_{\text {exc }}=488$ $\mathrm{nm}$ ) as standard. 
WILEY-VCH

\section{FULL PAPER}

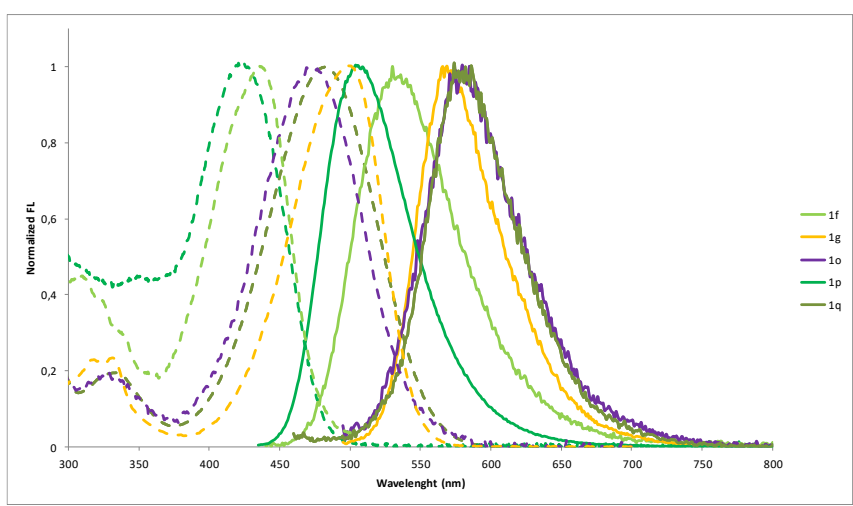

Figure 6. Normalized absorption (dashed lines) and emission (solid lines) spectra of oxazolones $\mathbf{2 f - 2} \mathbf{g}$, and imidazolones $\mathbf{2 0 - 2 q}$ in $\mathrm{CH}_{2} \mathrm{Cl}_{2}$ at $25^{\circ} \mathrm{C}$.

Table 2. Photophysical data for the orthopalladated analogs in dichloromethane at $25^{\circ} \mathrm{C}$.

\begin{tabular}{cccccc}
\hline Compound $^{[\mathrm{a}]}$ & $\begin{array}{c}\lambda_{\mathrm{abs}, \max } \\
{[\mathrm{nm}]}\end{array}$ & $\begin{array}{c}\varepsilon \\
{\left[\mathrm{M}^{-1} \mathrm{~cm}^{-1}\right]}\end{array}$ & $\begin{array}{c}\lambda_{\mathrm{em}, \max } \\
{[\mathrm{nm}]}\end{array}$ & $\Phi_{\mathrm{F}}^{[\mathrm{b}]}$ & $\begin{array}{c}\text { Stokes } \\
\text { shift }\left[\mathrm{cm}^{-1}\right]\end{array}$ \\
\hline $\mathbf{4 f}$ & 445 & 19195 & 524 & $0.018^{[\mathrm{c}]}$ & 3387 \\
$\mathbf{4 g}$ & 504 & 8084 & 555 & $0.008^{[\mathrm{d}]}$ & 1823 \\
$\mathbf{4 0}$ & 529 & 5405 & 597 & $0.042^{[\mathrm{d}]}$ & 2153 \\
$\mathbf{4 p}$ & 471 & 8115 & - & - & - \\
$\mathbf{4 q}$ & 534 & 29749 & 610 & $0.010^{[\mathrm{e}]}$ & 2333
\end{tabular}

[a] All spectra were recorded at $25{ }^{\circ} \mathrm{C}$. [b] Quantum yield $( \pm 10 \%)$ of fluorescence determined by using : [c] Coumarine-153 ( $\Phi_{\mathrm{F}}=0.38$ in $\left.\mathrm{EtOH}\right)$, $\lambda_{\text {exc }}=430$ or $450 \mathrm{~nm}$; or [d] Rhodamine $6 \mathrm{G}\left(\Phi_{\mathrm{F}}=0.94\right.$ in EtOH $), \lambda_{\text {exc }}=488$ $\mathrm{nm}$; or [e] Cresyl violet $\left(\Phi_{\mathrm{F}}=0.56 \mathrm{in} \mathrm{EtOH}\right), \lambda_{\mathrm{exc}}=550 \mathrm{~nm}$ as standard.

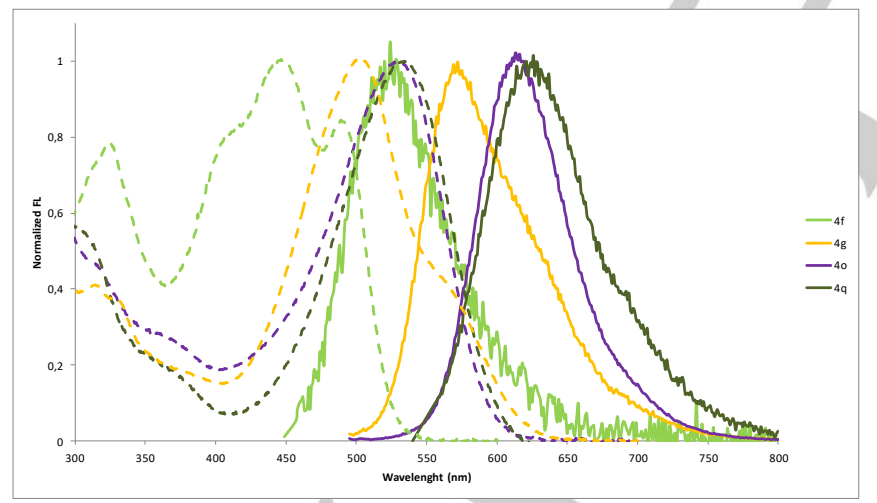

Figure 7. Normalized absorption (dashed lines) and emission (solid lines) spectra of orthopalladated oxazolones $\mathbf{4 f - 4} \mathbf{g}$ and imidazolones $\mathbf{4 0 - 4 q}$ in $\mathrm{CH}_{2} \mathrm{Cl}_{2}$ at $25^{\circ} \mathrm{C}$.

\section{Conclusions}

The orthopalladation of a wide array of 4-aryliden-5(4H)oxazolones and -imidazolones with different substituents at the 4arylidene ring and at the 2-position of the heterocycle takes place through $\mathrm{C}-\mathrm{H}$ bond activation with full regioselectivity, because only the ortho position of the 4-arylidene ring is activated. The resulting orthopalladated complexes have dimeric open-book structures with carboxylate bridges. The metathesis of the carboxylate ligands by chloride ligands afford dimeric planar complexes, which in turn react with acetylacetonate affording rigid neutral mononuclear complexes containing two chelating ligands, one $\mathrm{C}, \mathrm{N}$-orthopalladated oxazolone or imidazolone and one O,Oacac. The photophysical properties of these rigid mononuclear complexes have been examined and confirm the importance of rigidification of imidazolones. In addition, the high regioselectivities of palladation reactions makes this reaction interesting for future functionalizations. Development of a catalytic version of the reaction for further rigidification upon palladiummediated cyclisations is currently underway in our laboratory.

\section{Experimental Section}

1. General Remarks. Solvents were used as received from commercial sources. They were not distilled nor subjected to additional purification. Thin layer chromatographies (TLCs) were done on silica gel plates DCFertigfolien Polygram $®$ SIL G/UV254. Column liquid chromatography was performed on aluminum oxide 90 neutral $(50-200 \mu \mathrm{m})$ or silica gel (70-230 $\mu \mathrm{m})$ using the solvents specified on each case. Elemental analyses (CHNS) were carried out on a Perkin Elmer 2400 Series II microanalyser. ${ }^{1} \mathrm{H}$ and ${ }^{13} \mathrm{C}\left\{{ }^{1} \mathrm{H}\right\}$ NMR spectra were recorded in $\mathrm{CDCl}_{3}$ or $\mathrm{CD}_{2} \mathrm{Cl}_{2}$ solutions at $25^{\circ} \mathrm{C}$ on Bruker AV300 or AV400 spectrometers ( $\delta$ in ppm, $\mathrm{J}$ in $\mathrm{Hz}$ ) at a ${ }^{1} \mathrm{H}$ NMR operating frequency of 300.13 or $400.13 \mathrm{MHz}$, respectively. ${ }^{1} \mathrm{H}$ and ${ }^{13} \mathrm{C}$ NMR spectra were referenced using the solvent signal as an internal standard. The ESI $\left(\mathrm{ESI}^{+}\right)$mass spectra were recorded using an Esquire 3000 ion-trap mass spectrometer (Bruker Daltonic $\mathrm{GmbH}$ ) equipped with a standard ESI/APCI source. HRMS and ESI $\left(\mathrm{ESI}^{+}\right)$ mass spectra were recorded using an MicroToF Q, API-Q-ToF ESI with a mass range from 20 to $3000 \mathrm{~m} / \mathrm{z}$ and mass resolution 15000 (FWHM). UV/Vis spectra were recorded with a Varian Can 50 scan spectrophotometer by using a rectangular quartz cell (Varian, standard cell, Open Top, light path $10 \times 10 \mathrm{~mm}$, chamber volume: $3.5 \mathrm{~mL}$ ). Fluorescence spectroscopic studies (emission/excitation spectra) were performed with a Varian Cary Eclipse spectrophotometer with a semi-micro quartz fluorescence cell (Hellma, 104F-QS, light path, 10×4 mm, chamber volume $1400 \mu \mathrm{L}$, excitation filter: auto and emission filter: open, excitation and emission slit: $5 \mathrm{~nm}$ ). Fluorescence quantum yields were measured at 25 ${ }^{\circ} \mathrm{C}$ by a relative method using Cresyl Violet $\left(\Phi_{\mathrm{F}}=56 \%\right.$ in EtOH $)$, Coumarine $153\left(\Phi_{\mathrm{F}}=38 \%\right.$ in $\left.\mathrm{EtOH}\right)$, or Rhodamine $6 \mathrm{G}\left(\Phi_{\mathrm{F}}=94 \%\right.$ in $\left.\mathrm{EtOH}\right)$, as a standard. The following equation was used to determine the relative fluorescence quantum yield:

$$
\Phi_{F}(x)=\frac{A_{s}}{A_{x}} \times \frac{F_{x}}{F_{s}} \times\left(\frac{n_{x}}{n_{s}}\right)^{2} \Phi_{F}(s)
$$

Where $A$ is the absorbance (in the range of $0.01-0.1 \mathrm{~A}$. U.), $\mathrm{F}$ is the area under the emission curve, $n$ is the refractive index of the solvents (at 25 ${ }^{\circ} \mathrm{C}$ ) used in measurements, and the subscripts $s$ and $x$ represent standard and unknown, respectively. The following refractive index values were used: 1.361 for $\mathrm{EtOH}$ and 1.421 for $\mathrm{CH}_{2} \mathrm{Cl}_{2}$ ). The oxazolones containing the phenyl ring at 2-position (1a-1e), ${ }^{[27-37]}$ those containing the methyl group at 2-position $(\mathbf{1} \mathbf{h}-\mathbf{1} \mathbf{j}),{ }^{[38-44]}$ and the orthopalladated complexes $\mathbf{2 a -}$ $\mathbf{2 e},{ }^{[80]}$ have been prepared by reported procedures. Compound $4 \mathbf{a}$ has been reported by us elsewhere, but the method described here is slightly different. ${ }^{[82]}$

2. General synthesis of the imidazolones $\mathbf{1 k - 1 q}$. The synthesis of the imidazolones $\mathbf{1 k - 1 q}$ has been carried out following previously reported methods with some minor modifications. ${ }^{[26]}$ Imidazolone 1q was prepared via $\mathrm{C}-\mathrm{H}$ arylation by reported procedures. ${ }^{[25]}$ The yellow or orange starting oxazolone $(1.36 \mathrm{mmol})$ was suspended in pyridine $(4 \mathrm{~mL})$ and treated with 
n-propylamine $(11.2 \mu \mathrm{L}, 1.36 \mathrm{mmol})$ with strong stirring for 20 minutes at $25^{\circ} \mathrm{C}$. A white suspension is formed at this point. After this time, bis(trimethylsilyl)acetamide $(66.7 \mu \mathrm{L}, 2.73 \mathrm{mmol})$ was added, and the resulting mixture was stirred while heated at $110^{\circ} \mathrm{C}$ for $15 \mathrm{~h}$. After the reaction time, the cool suspension was evaporated to dryness. The remaining residue was redissolved in the minimal amount of $\mathrm{CH}_{2} \mathrm{Cl}_{2}$ (1-2 $\mathrm{mL}$ ) and treated with $n$-hexane $(10 \mathrm{~mL})$. A cream-colored solid precipitated which was filtered, dried by suction, and characterized as the imidazolone $\mathbf{1 k - 1 q}$. The characterization of $\mathbf{1 k}$ is shown here, that of imidazolones $\mathbf{1 l}-$ $\mathbf{1 q}$ is given as Supporting Information.

Synthesis of 1k. Beige solid. Yield: $82 \%$. ${ }^{1} \mathrm{H} \mathrm{NMR}\left(300.13 \mathrm{MHz}, \mathrm{CDCl}_{3}\right.$, r.t.): $\delta=8.96\left(\mathrm{dd}, 1 \mathrm{H}, \mathrm{C}_{6} \mathrm{H}_{4} \mathrm{Cl},{ }^{3} \mathrm{~J}_{\mathrm{HH}}=7.5\right), 7.76\left(\mathrm{dm}, 2 \mathrm{H}, \mathrm{H}_{\mathrm{o}}, \mathrm{C}_{6} \mathrm{H}_{5},{ }^{3} \mathrm{~J}_{\mathrm{HH}}=\right.$ 7.8), $7.71(\mathrm{~s}, 1 \mathrm{H},=\mathrm{CH}), 7.53-7.50\left(\mathrm{~m}\right.$, broad, $\left.3 \mathrm{H}, \mathrm{H}_{\mathrm{p}}+\mathrm{H}_{\mathrm{m}}\left(\mathrm{C}_{6} \mathrm{H}_{5}\right)\right), 7.38(\mathrm{dd}$ $\left.1 \mathrm{H}, \mathrm{C}_{6} \mathrm{H}_{4} \mathrm{Cl},{ }^{3} \mathrm{~J}_{\mathrm{HH}}=7.4\right), 7.27-7.23\left(\mathrm{~m}, 2 \mathrm{H}, \mathrm{C}_{6} \mathrm{H}_{4} \mathrm{Cl}\right), 3.73\left(\mathrm{~m}, 2 \mathrm{H}, \mathrm{NCH}_{2}\right)$, $1.57\left(\mathrm{tq}, 2 \mathrm{H}, \mathrm{CH}_{2},{ }^{3} \mathrm{~J}_{\mathrm{HH}}=7.5\right), 0.82\left(\mathrm{t}, 3 \mathrm{H}, \mathrm{Me},{ }^{3} \mathrm{~J}_{\mathrm{HH}}=7.4\right) .{ }^{13} \mathrm{C}\left\{{ }^{1} \mathrm{H}\right\} \mathrm{NMR}$ (75.47 MHz, $\mathrm{CDCl}_{3}$, r.t.): $\delta=171.5(\mathrm{C}=\mathrm{O}), 164.0(\mathrm{CN}), 140.0(\mathrm{C}=), 136.4$ $\left(\mathrm{C}-\mathrm{Cl}, \mathrm{C}_{6} \mathrm{H}_{4} \mathrm{Cl}\right), 133.8\left(\mathrm{CH}, \mathrm{C}_{6} \mathrm{H}_{4} \mathrm{Cl}\right), 132.2\left(\mathrm{C}, \mathrm{C}_{6} \mathrm{H}_{4} \mathrm{Cl}\right), 131.6\left(\mathrm{C}_{\mathrm{p}}, \mathrm{C}_{6} \mathrm{H}_{5}\right)$, $131.0\left(\mathrm{CH}, \mathrm{C}_{6} \mathrm{H}_{4} \mathrm{Cl}\right), 129.7\left(\mathrm{CH}, \mathrm{C}_{6} \mathrm{H}_{4} \mathrm{Cl}\right), 129.6\left(\mathrm{C}_{\mathrm{i}}, \mathrm{C}_{6} \mathrm{H}_{5}\right), 128.9\left(\mathrm{C}_{\mathrm{m}}\right.$, $\left.\mathrm{C}_{6} \mathrm{H}_{5}\right), 128.3\left(\mathrm{C}_{\mathrm{o}}, \mathrm{C}_{6} \mathrm{H}_{5}\right), 127.0\left(\mathrm{CH}, \mathrm{C}_{6} \mathrm{H}_{4} \mathrm{Cl}\right), 123.2(=\mathrm{CH}), 43.4\left(\mathrm{NCH}_{2}\right)$, $22.4\left(\mathrm{CH}_{2}\right), 11.1\left(\mathrm{CH}_{3}\right)$. HRMS (ESI-TOF): $\mathrm{m} / \mathrm{z}$ calcd for $\mathrm{C}_{19} \mathrm{H}_{18} \mathrm{CIN}_{2} \mathrm{O}$ : $325.1108[\mathrm{M}+\mathrm{H}]^{+}$; found 325.1114 .

3. General synthesis of the orthopalladated derivatives $2 \mathrm{~h}-2 \mathrm{q}$ through C-H activation. Method $A$ (compounds $\mathbf{2 h}-\mathbf{2 j}$ ): To a suspension of $\mathrm{Pd}(\mathrm{OAc})_{2}(100 \mathrm{mg}, 0.44 \mathrm{mmol})$ in $\mathrm{CH}_{3} \mathrm{CO}_{2} \mathrm{H}(8 \mathrm{~mL})$, the stoichiometric amount of the oxazolones $\mathbf{1 h} \mathbf{- 1} \mathbf{j}(0.44 \mathrm{mmol}, 1: 1$ molar ratio) was added. The resulting suspension was heated to $120^{\circ} \mathrm{C}$ for $1 \mathrm{~h}$. During this time, the suspension changes notably its aspect, from a brown color to a yellow or yellowish-orange color. After the reaction time, the resulting suspension was cooled to room temperature, and then treated with water $(15 \mathrm{~mL})$. The amount of precipitated solid increases notably. This solid was filtered, washed with additional water until the typical smell of acetic acid was not detected $(2 \times 15 \mathrm{~mL})$, dried by suction, and characterized as complexes $\mathbf{2} \mathbf{h}$ 2j. Method $B$ (compounds 2g, 2k-2q): To a suspension of $\mathrm{Pd}(\mathrm{OAc})_{2}(1$ equiv.) in $\mathrm{CF}_{3} \mathrm{CO}_{2} \mathrm{H}$, the stoichiometric amount of the oxazolone $1 \mathrm{~g}$ or the imidazolone $\mathbf{1 k - 1 q}$ (1:1 molar ratio) was added. The resulting suspension was heated to $75^{\circ} \mathrm{C}$ for $4 \mathrm{~h}$. During this time, the suspension changes notably its aspect, from a brown color to a yellow or red color. After the reaction time, the resulting suspension was cooled to room temperature, and then treated with water $(25 \mathrm{~mL})$. The amount of precipitated solid increased. This solid was filtered, washed with additional water until the strong smell of $\mathrm{CF}_{3} \mathrm{CO}_{2} \mathrm{H}$ was not detected $(2 \times 25 \mathrm{~mL})$, dried in vacuo, and characterized as complexes $\mathbf{2 g}$, or $\mathbf{2 k - 2 q}$. Method $C$ (Compounds $\mathbf{2 f}, \mathbf{2} \mathbf{p}$ ): To a suspension of $\mathrm{Pd}(\mathrm{OAc})_{2}$ (1 equiv.) in $\mathrm{CF}_{3} \mathrm{CO}_{2} \mathrm{H}$, the stoichiometric amount of the imidazolone 1 or $1 p$ (1:1 molar ratio) was added. The resulting suspension was stirred at room temperature for $2 \mathrm{~h}$. During this time, the suspension changes notably its aspect, from a brown color to a yellow or red color. After the reaction time, the resulting suspension was treated with water $(25 \mathrm{~mL})$. The amount of precipitated solid increased. This solid was filtered, washed with additional water until the strong smell of $\mathrm{CF}_{3} \mathrm{CO}_{2} \mathrm{H}$ was not detected $(2 \times 25 \mathrm{~mL})$, dried in vacuo, and characterized as complexes $2 \mathbf{f}$ or $\mathbf{2 p}$. The characterization of complexes $\mathbf{2 j}, \mathbf{2 k}$ and $\mathbf{2 p}$ is shown here, that of the remaining orthopalladated derivatives is given as Supporting Information.

Synthesis of 2j. Method A. Yellowish-orange solid, Obtained: $157 \mathrm{mg}$ (100\% yield). ${ }^{1} \mathrm{H}$ NMR $\left(400.13 \mathrm{MHz}, \mathrm{CDCl}_{3}, 298 \mathrm{~K}\right): \delta=7.55\left(\mathrm{~d}, 1 \mathrm{H}, \mathrm{SC}_{4} \mathrm{H}_{2}\right.$ $\left.{ }^{3} \mathrm{~J}_{\mathrm{HH}}=5.0\right), 7.31(\mathrm{~s}, 1 \mathrm{H},=\mathrm{CH}), 7.04\left(\mathrm{~d}, 1 \mathrm{H}, \mathrm{SC}_{4} \mathrm{H}_{2},{ }^{3} \mathrm{~J}_{\mathrm{HH}}=5.0\right), 2.19(\mathrm{~s}, 3 \mathrm{H}$, $\left.\mathrm{CH}_{3} \mathrm{C}=\mathrm{N}\right), 2.12\left(\mathrm{~s}, 3 \mathrm{H}, \mathrm{CH}_{3} \mathrm{COO}\right) \cdot{ }^{13} \mathrm{C}\left\{{ }^{1} \mathrm{H}\right\} \mathrm{NMR}\left(100.6 \mathrm{MHz}, \mathrm{CDCl}_{3}, 298\right.$ $\mathrm{K}): \delta=182.0(\mathrm{AcO}), 169.8(\mathrm{C}=\mathrm{O}), 161.3(\mathrm{C}=\mathrm{N}), 141.7(\mathrm{C}), 134.2(\mathrm{CH})$, $132.8(\mathrm{CH}), 128.7(\mathrm{CH}), 127.3(\mathrm{C}), 118.7(\mathrm{C}), 24.4$ (s, $\left.\mathrm{CH}_{3} \mathrm{COO}\right), 15.6$ (s, $\mathrm{CH}_{3} \mathrm{C}=\mathrm{N}$ ). $\mathrm{HRMS}$ (ESI-TOF): $\mathrm{m} / \mathrm{z}$ calcd for $\mathrm{C}_{22} \mathrm{H}_{18} \mathrm{~N}_{2} \mathrm{NaO}_{8} \mathrm{Pd}_{2} \mathrm{~S}_{2}: 738.8478$ $[\mathrm{M}+\mathrm{Na}]^{+}$; found: 738.8475 . IR $\left(\mathrm{v}, \mathrm{cm}^{-1}\right): 1797,1773$ vs $(\mathrm{C}=\mathrm{O}), 1626$ vs $(\mathrm{C}=\mathrm{N})$. Elemental analysis calcd for $\mathrm{C}_{22} \mathrm{H}_{18} \mathrm{~N}_{2} \mathrm{O}_{8} \mathrm{Pd}_{2} \mathrm{~S}_{2}$ : C 36.94, $\mathrm{H} 2.54, \mathrm{~N}$ 3.92, S 8.96; found: C 37.15, H 2.77, N 3.80, S, 8.64.
Synthesis of 2k. Method B. $\mathrm{Pd}(\mathrm{OAc})_{2}(691 \mathrm{mg}, 3.1 \mathrm{mmol})$ was reacted with $1 \mathbf{k}(1000 \mathrm{mg}, 3.1 \mathrm{mmol})$ in $\mathrm{CF}_{3} \mathrm{COOH}(10 \mathrm{~mL})$ to give $\mathbf{2 k}$ as a red solid. Obtained: $1470 \mathrm{mg}, 98 \%$ yield. ${ }^{1} \mathrm{H}$ NMR $\left(300.13 \mathrm{MHz}, \mathrm{CDCl}_{3}\right.$, r.t.): $\delta=8.14(\mathrm{~s}, 1 \mathrm{H},=\mathrm{CH}), 7.50\left(\mathrm{t}, 1 \mathrm{H}, \mathrm{H}_{\mathrm{p}}, \mathrm{C}_{6} \mathrm{H}_{5},{ }^{3} \mathrm{~J}_{\mathrm{HH}}=7.5\right), 7.37\left(\mathrm{t}, 2 \mathrm{H}, \mathrm{H}_{\mathrm{m}}\right.$, $\left.\mathrm{C}_{6} \mathrm{H}_{5},{ }^{3} \mathrm{~J}_{\mathrm{HH}}=7.5\right), 7.31\left(\mathrm{dd}, 1 \mathrm{H}, \mathrm{C}_{6} \mathrm{H}_{3},{ }^{3} \mathrm{JHH}_{\mathrm{HH}}=8,{ }^{4} \mathrm{~J}_{\mathrm{HH}}=2\right), 7.10$ (d, broad, $\left.1 \mathrm{H}, \mathrm{C}_{6} \mathrm{H}_{3},{ }^{3} \mathrm{~J}_{\mathrm{HH}}=7.5\right), 7.03\left(\mathrm{dd}, 1 \mathrm{H}, \mathrm{C}_{6} \mathrm{H}_{3},{ }^{3} \mathrm{~J}_{\mathrm{HH}}=8\right), 6.95$ (d, very broad, $2 \mathrm{H}, \mathrm{H}_{0}, \mathrm{C}_{6} \mathrm{H}_{5}$ ), 3.69 (ddd, $1 \mathrm{H}, \mathrm{NCH}_{2},{ }^{2} \mathrm{~J}_{\mathrm{HH}}=15,{ }^{3} \mathrm{JHH}=9,{ }^{3} \mathrm{JHH}_{\mathrm{HH}}=6$ ), 3.21 (ddd, $\left.1 \mathrm{H}, \mathrm{NCH}_{2},{ }^{2} \mathrm{~J}_{\mathrm{HH}}=15,{ }^{3} \mathrm{JHH}=9,{ }^{3} \mathrm{JHH}_{\mathrm{HH}}=6\right), 1.34-1.13\left(\mathrm{~m}, 2 \mathrm{H}, \mathrm{CH}_{2}\right.$ ), $0.64\left(\mathrm{t}, 3 \mathrm{H}, \mathrm{Me},{ }^{3} \mathrm{~J}_{\mathrm{HH}}=7.5 \mathrm{~Hz}\right) \cdot{ }^{13} \mathrm{C}\left\{{ }^{1} \mathrm{H}\right\} \operatorname{NMR}\left(75.47 \mathrm{MHz}, \mathrm{CDCl}_{3}\right.$, r.t. $): \delta=$ $166.5(\mathrm{C}=\mathrm{N}), 164.2(\mathrm{CO}), 164.1\left(\mathrm{q}, \mathrm{CF}_{3} \mathrm{CO}_{2},{ }^{2} \mathrm{~J}_{\mathrm{CF}}=38.5\right), 137.8(=\mathrm{C})$, $134.9\left(\mathrm{C}-\mathrm{Cl}, \mathrm{C}_{6} \mathrm{H}_{3}\right), 133.1\left(\mathrm{CH}, \mathrm{C}_{6} \mathrm{H}_{3}\right), 132.5\left(\mathrm{C}_{p}, \mathrm{C}_{6} \mathrm{H}_{5}\right), 130.4\left(\mathrm{C}, \mathrm{C}_{6} \mathrm{H}_{3}\right)$, $129.5\left(\mathrm{CH}, \mathrm{C}_{6} \mathrm{H}_{3}\right), 129.2(=\mathrm{CH}), 128.7\left(\mathrm{C}_{\mathrm{m}}, \mathrm{C}_{6} \mathrm{H}_{5}\right), 128.4\left(\mathrm{C}_{\mathrm{o}}, \mathrm{C}_{6} \mathrm{H}_{5}\right), 127.2$ $\left(\mathrm{C}, \mathrm{C}_{6} \mathrm{H}_{3}\right), 126.7\left(\mathrm{CH}, \mathrm{C}_{6} \mathrm{H}_{3}\right), 126.2\left(\mathrm{C}_{\mathrm{i}}, \mathrm{C}_{6} \mathrm{H}_{5}\right), 114.4\left(\mathrm{q}, \mathrm{CF}_{3},{ }^{1} \mathrm{~J}_{\mathrm{CF}}=288\right)$, $43.5\left(\mathrm{NCH}_{2}\right), 21.5\left(\mathrm{CH}_{2}\right), 10.8\left(\mathrm{CH}_{3}\right){ }^{19} \mathrm{~F}$ NMR $\left(282.40 \mathrm{MHz}, \mathrm{CDCl}_{3}\right.$, r.t.): $\delta=-74.35$ (s). HRMS (ESI-TOF) $\mathrm{m} / \mathrm{z}:\left[\mathrm{M}+\mathrm{CF}_{3} \mathrm{CO}_{2}\right]^{-}$calcd for $\mathrm{C}_{44} \mathrm{H}_{32} \mathrm{Cl}_{2} \mathrm{~F}_{9} \mathrm{~N}_{4} \mathrm{O}_{8} \mathrm{Pd}_{2} 1194.9555$, obtained 1194.9554.

Synthesis of 2p. Method C. $\mathrm{Pd}(\mathrm{OAC})_{2}(172 \mathrm{mg}, 0.89 \mathrm{mmol})$ was reacted with $1 \mathrm{p}(300 \mathrm{mg}, 0.89 \mathrm{mmol})$ in $\mathrm{CF}_{3} \mathrm{COOH}(6 \mathrm{~mL})$ to give $2 p$ as a yellow solid. Obtained: $312 \mathrm{mg}, 75 \%$ yield. This compound was too insoluble in usual deuterated solvents to perform a proper characterization by NMR methods. Only IR and HRMS data could be obtained. IR $\left(\mathrm{v}, \mathrm{cm}^{-1}\right): 1783 \mathrm{vs}$ (C=O).HRMS (ESI-TOF) $\mathrm{m} / \mathrm{z}$ : $\left[\mathrm{M}+\mathrm{CF}_{3} \mathrm{CO}_{2}\right]^{-}$calcd for $\mathrm{C}_{48} \mathrm{H}_{42} \mathrm{~F}_{9} \mathrm{~N}_{6} \mathrm{O}_{8} \mathrm{Pd}_{2}$ 1213.1178, obtained 1213.1191.

4. General synthesis of the orthopalladated chloride-bridge derivatives $\mathbf{3 a - 3 q}$. The synthesis of $\mathbf{3 a}$ from $\mathbf{2} \mathbf{a}$ is detailed here. The synthesis of $\mathbf{3 b} \mathbf{b} \mathbf{3} \mathbf{q}$ has been carried using the same experimental method from the respective starting materials $\mathbf{2 b - 2 q}$, which are detailed in the Supporting Information. To a suspension of $2 \mathrm{a}(475.2 \mathrm{mg}, 0.51 \mathrm{mmol})$ in methanol $(20 \mathrm{~mL})$ at room temperature, $\mathrm{LiCl}(86 \mathrm{mg}, 2.03 \mathrm{mmol})$ was added. The resulting suspension was stirred at room temperature for $24 \mathrm{~h}$, then filtered through a glass sintered funnel. The precipitated solid was kept, and the solution was discarded. This solid was washed with cold methanol $(5 \mathrm{~mL})$ and $\mathrm{Et}_{2} \mathrm{O}(20 \mathrm{~mL})$, dried by suction, and characterized as 3a. Obtained: $266.6 \mathrm{mg}(67.2 \%$ yield $)$

Synthesis of 3a. Deep yellow solid. Obtained: $266.6 \mathrm{mg}(67.2 \%$ yield) IR $\left(\mathrm{v}, \mathrm{cm}^{-1}\right): 1785 \mathrm{vs}(\mathrm{C}=\mathrm{O}), 262 \mathrm{w}\left(\mathrm{Pd}_{2}(\mu-\mathrm{Cl})_{2}\right)$. Elemental analysis found: C, 49.15; $\mathrm{H}, 2.57 ; \mathrm{N}, 3.82$. Calculated for $\mathrm{C}_{32} \mathrm{H}_{20} \mathrm{Cl}_{2} \mathrm{~N}_{2} \mathrm{O}_{4} \mathrm{Pd}_{2}$ : C, 49.26; $\mathrm{H}$, $2.58 ; \mathrm{N}, 3.59$.

5. General synthesis of the orthopalladated acetylacetonate derivatives $4 a-4 q$. The synthesis of $4 a$ has been reported by us elsewhere, ${ }^{[82]}$ but using a slightly different starting material. The characterization of complex $4 \mathbf{a}$ here prepared is provided for comparative purposes. ${ }^{[82]}$ The synthesis of $\mathbf{4 b}$ is described here in detail. Method $A$. To a suspension of $\mathbf{3 b}(463 \mathrm{mg}, 0.545 \mathrm{mmol})$ in $\mathrm{CH}_{2} \mathrm{Cl}_{2}(15 \mathrm{~mL})$ at room temperature, $\mathrm{Tl}(\mathrm{acac})(331 \mathrm{mg}, 1.09 \mathrm{mmol})$ was added. The resulting suspension was stirred at room temperature for $4 \mathrm{~h}$, then filtered through celite to remove the solid $\mathrm{TICl}$ formed during the reaction. The clear solution was evaporated to dryness, and the solid residue was treated with cold $n$-hexane $(25 \mathrm{~mL})$. Further stirring produced the formation of a solid, which was filtered, washed with additional cold $n$-hexane $(10 \mathrm{~mL})$, dried by suction and characterized as $\mathbf{4 b}$. Other acetylacetonates obtained using this method are given as Supporting Information.

Synthesis of $\mathbf{4 b}$. Deep yellow solid. Obtained: $324.1 \mathrm{mg}(60.8 \%$ yield $)$. ${ }^{1} \mathrm{H}$ NMR $\left(300.13 \mathrm{MHz}, \mathrm{CDCl}_{3}, 298 \mathrm{~K}\right): \delta=8.43\left(\mathrm{~d}, 2 \mathrm{H}, \mathrm{H}_{\mathrm{o}}, \mathrm{C}_{6} \mathrm{H}_{5},{ }^{3} \mathrm{~J}_{\mathrm{HH}}=8\right)$, $8.26(\mathrm{~s}, 1 \mathrm{H},=\mathrm{CH}), 7.68-7.63\left(\mathrm{~m}, 2 \mathrm{H}, \mathrm{PdC}_{6} \mathrm{H}_{3}(1 \mathrm{H})+\mathrm{H}_{\mathrm{p}}, \mathrm{C}_{6} \mathrm{H}_{5}\right), 7.52(\mathrm{t}, 2 \mathrm{H}$, $\mathrm{H}_{\mathrm{m}}, \mathrm{C}_{6} \mathrm{H}_{5}$ ), 7.23-7.13 (m, 2H, $\left.\mathrm{PdC}_{6} \mathrm{H}_{3}\right), 5.22$ (s, 1H, $\mathrm{C}_{3}-\mathrm{H}$, acac), 2.03 (s, $3 \mathrm{H}, \mathrm{Me}, \mathrm{acac}), 1.23$ (s, 3H, Me, acac). ${ }^{13} \mathrm{C}\left\{{ }^{1} \mathrm{H}\right\} \mathrm{NMR}\left(75.47 \mathrm{MHz}, \mathrm{CDCl}_{3}\right.$, $298 \mathrm{~K}): \delta=187.1$ (CO, acac), $186.0(\mathrm{CO}, \mathrm{acac}), 167.0(\mathrm{C}=\mathrm{N}), 161.5\left(\mathrm{CO}_{2}\right)$, $148.7\left(\mathrm{C}, \mathrm{PdC}_{6} \mathrm{H}_{3}\right), 135.5(=\mathrm{CH}-), 135.4\left(\mathrm{C}, \mathrm{PdC}_{6} \mathrm{H}_{3}\right), 134.2\left(\mathrm{C}_{\mathrm{p}}, \mathrm{C}_{6} \mathrm{H}_{5}\right)$, 133.6 ( $\left.\mathrm{CH}, \mathrm{PdC}_{6} \mathrm{H}_{3}\right), 130.9\left(\mathrm{CH}, \mathrm{PdC}_{6} \mathrm{H}_{3}\right), 130.7\left(\mathrm{C}_{\circ}, \mathrm{C}_{6} \mathrm{H}_{5}\right), 129.8(=\mathrm{C})$, $128.0\left(\mathrm{C}_{\mathrm{m}}, \mathrm{C}_{6} \mathrm{H}_{5}\right), 126.5\left(\mathrm{CH}, \mathrm{PdC}_{6} \mathrm{H}_{3}\right), 124.9\left(\mathrm{C}, \mathrm{PdC}_{6} \mathrm{H}_{3}\right), 124.0\left(\mathrm{C}_{\mathrm{i}}, \mathrm{C}_{6} \mathrm{H}_{5}\right)$, 


\section{WILEY-VCH}

\section{FULLPAPER}

$100.0\left(\mathrm{C}_{3} \mathrm{H}, \mathrm{acac}\right), 27.4$ (Me, acac), 26.4 (Me, acac). HRMS (ESI+) [m/z] Calc. for $\mathrm{C}_{21} \mathrm{H}_{16} \mathrm{ClNO}_{4} \mathrm{Pd}[\mathrm{M}]^{+}$: 486.9803, obtained 486.9813 .

Synthesis of 4a. Complex 4a was obtained from 3a $(458.4 \mathrm{mg}, 0.587$ $\mathrm{mmol}$ ) and $\mathrm{Tl}(\mathrm{acac})(356.6 \mathrm{mg}, 1.175 \mathrm{mmol})$ following the same experimental method than that described for $\mathbf{4 b}$. Yellow solid. Obtained: $304.4 \mathrm{mg}\left(57 \%\right.$ yield). ${ }^{1} \mathrm{H}$ NMR $\left(300.13 \mathrm{MHz}, \mathrm{CDCl}_{3}, 298 \mathrm{~K}\right): \delta=8.44(\mathrm{~d}$, $\left.2 \mathrm{H}, \mathrm{H}_{\mathrm{o}}, \mathrm{C}_{6} \mathrm{H}_{5},{ }^{3} \mathrm{~J}_{\mathrm{HH}}=7.5\right), 7.81\left(\mathrm{dd}, 1 \mathrm{H}, \mathrm{PdC}_{6} \mathrm{H}_{4},{ }^{3} \mathrm{~J}_{\mathrm{HH}}=8.0,{ }^{4} \mathrm{~J}_{\mathrm{HH}}=1.1\right)$, $7.64\left(\mathrm{tt}, 1 \mathrm{H}, \mathrm{H}_{\mathrm{p}}, \mathrm{C}_{6} \mathrm{H}_{5},{ }^{3} \mathrm{~J}_{\mathrm{HH}}=7.8,{ }^{4} \mathrm{~J}_{\mathrm{HH}}=0.8\right), 7.61(\mathrm{~s}, 1 \mathrm{H},=\mathrm{CH}), 7.51(\mathrm{t}$, $\left.2 \mathrm{H}, \mathrm{H}_{\mathrm{m}}, \mathrm{C}_{6} \mathrm{H}_{5}\right), 7.33-7.29\left(\mathrm{~m}, 2 \mathrm{H}, \mathrm{PdC}_{6} \mathrm{H}_{4}\right), 7.17\left(\mathrm{td}, 1 \mathrm{H}, \mathrm{PdC}_{6} \mathrm{H}_{4},{ }^{3} \mathrm{~J}_{\mathrm{HH}}=\right.$ $\left.7.8,{ }^{4} \mathrm{~J}_{\mathrm{HH}}=1.2\right), 5.22\left(\mathrm{~s}, 1 \mathrm{H}, \mathrm{C}_{3}-\mathrm{H}, \mathrm{acac}\right), 2.05(\mathrm{~s}, 3 \mathrm{H}, \mathrm{Me}, \mathrm{acac}), 1.23(\mathrm{~s}$, $3 \mathrm{H}, \mathrm{Me}, \mathrm{acac}) \cdot{ }^{13} \mathrm{C}\left\{{ }^{1} \mathrm{H}\right\} \mathrm{NMR}\left(75.47 \mathrm{MHz}, \mathrm{CDCl}_{3}, 298 \mathrm{~K}\right): \delta=187.1(\mathrm{CO}$ acac), 186.1 (CO, acac), $166.3(\mathrm{C}=\mathrm{N}), 161.8\left(\mathrm{CO}_{2}\right), 145.9\left(\mathrm{C}, \mathrm{PdC}_{6} \mathrm{H}_{4}\right)$, $140.6(=\mathrm{CH}-), 134.8\left(\mathrm{CH}, \mathrm{PdC}_{6} \mathrm{H}_{4}\right), 133.9\left(\mathrm{C}_{p}, \mathrm{C}_{6} \mathrm{H}_{5}\right), 132.9\left(\mathrm{CH}, \mathrm{PdC}_{6} \mathrm{H}_{4}\right)$, $132.7(=\mathrm{C}), 131.0\left(\mathrm{CH}, \mathrm{PdC}_{6} \mathrm{H}_{4}\right), 130.6\left(\mathrm{C}_{0}, \mathrm{C}_{6} \mathrm{H}_{5}\right), 127.9\left(\mathrm{Cm}_{\mathrm{m}}, \mathrm{C}_{6} \mathrm{H}_{5}\right), 125.3$ $\left(\mathrm{CH}, \mathrm{PdC}_{6} \mathrm{H}_{4}\right), 124.3\left(\mathrm{C}, \mathrm{PdC}_{6} \mathrm{H}_{4}\right), 123.4\left(\mathrm{C}_{\mathrm{i}}, \mathrm{C}_{6} \mathrm{H}_{5}\right), 99.9\left(\mathrm{C}_{3} \mathrm{H}, \mathrm{acac}\right), 27.5$ (Me, acac), 26.5 (Me, acac). HRMS (ESI ${ }^{+}$[ [m/z]: Calc. for $\mathrm{C}_{21} \mathrm{H}_{17} \mathrm{NNaO}_{4} \mathrm{Pd}$ $[\mathrm{M}+\mathrm{Na}]^{+}:$476.0093, obtained 476.0076.

Synthesis of $\mathbf{4 k}$. The synthesis of $\mathbf{4 k}$ is described here in detail. Other acetylacetonates obtained using this method are given as Supporting Information. Method B. Acetylacetone ( $33 \mathrm{mg}, 0.329 \mathrm{mmol}$ ) and $\mathrm{KOH}$ (18 $\mathrm{mg}, 0.329 \mathrm{mmol})$ in $\mathrm{MeOH}(10 \mathrm{~mL})$ were stirred at room temperature during $15 \mathrm{~min}$. Then, $\mathbf{3 k}(139 \mathrm{mg}, 0.149 \mathrm{mmol})$ was added and stirred at room temperature during 2 hours. The solution was evaporated to dryness, and the solid residue was washed with $\mathrm{H}_{2} \mathrm{O}$. The remaining residue was redissolved in the minimal amount of $\mathrm{CH}_{2} \mathrm{Cl}_{2}(1-2 \mathrm{~mL})$ and treated with petroleum ether $(10 \mathrm{~mL})$. A solid precipitated, which was filtered, dried by suction, and identified as 4k. Orange solid. Obtained: $76 \mathrm{mg}(97 \%$ yield). ${ }^{1} \mathrm{H} \mathrm{NMR}\left(300.13 \mathrm{MHz}, \mathrm{CDCl}_{3}, 298 \mathrm{~K}\right): \delta=8.21(\mathrm{~s}, 1 \mathrm{H},=\mathrm{CH}-), 7.90(\mathrm{~d}, 2 \mathrm{H}$, $\left.\mathrm{H}_{\mathrm{o}}, \mathrm{C}_{6} \mathrm{H}_{5},{ }^{3} \mathrm{~J}_{\mathrm{HH}}=7.5\right), 7.65\left(\mathrm{~d}, 1 \mathrm{H}, \mathrm{C}_{6} \mathrm{H}_{3} \mathrm{Pd},{ }^{3} \mathrm{~J}_{\mathrm{HH}}=7.5\right), 7.59-7.54(\mathrm{~m}, 3 \mathrm{H}$, $\left.\mathrm{H}_{\mathrm{m}}+\mathrm{H}_{\mathrm{p}}, \mathrm{C}_{6} \mathrm{H}_{5}\right), 7.18\left(\mathrm{~d}, 1 \mathrm{H}, \mathrm{C}_{6} \mathrm{H}_{3} \mathrm{Pd},{ }^{3} \mathrm{~J}_{\mathrm{HH}}=7.5\right), 7.09\left(\mathrm{t}, 1 \mathrm{H}, \mathrm{C}_{6} \mathrm{H}_{3} \mathrm{Pd},{ }^{3} \mathrm{~J}_{\mathrm{HH}}\right.$ $=7.7), 5.06\left(\mathrm{~s}, 1 \mathrm{H}, \mathrm{C}_{3}-\mathrm{H}, \mathrm{acac}\right), 3.75\left(\mathrm{t}, 2 \mathrm{H}, \mathrm{NCH}_{2},{ }^{3} \mathrm{~J}_{\mathrm{HH}}=6.7\right), 1.93(\mathrm{~s}, 3 \mathrm{H}$, $\mathrm{Me}$, acac), $1.53\left(\mathrm{~m}, 2 \mathrm{H}, \mathrm{CH}_{2},{ }^{\mathrm{n}} \mathrm{Pr}\right), 1.18\left(\mathrm{~s}, 3 \mathrm{H}, \mathrm{Me}\right.$, acac), $0.79\left(\mathrm{t}, 3 \mathrm{H}, \mathrm{CH}_{3}\right.$, $\left.{ }^{\mathrm{nPr}},{ }^{3} \mathrm{~J}_{\mathrm{HH}}=6.6\right) .{ }^{13} \mathrm{C}\left\{{ }^{1} \mathrm{H}\right\} \mathrm{NMR}\left(75.47 \mathrm{MHz}, \mathrm{CDCl}_{3}, 298 \mathrm{~K}\right): \delta=187.0(\mathrm{CO}$, acac), 185.7 (CO, acac), $166.1(\mathrm{C}=\mathrm{O}), 164.1(\mathrm{C}=\mathrm{N}), 148.2\left(\mathrm{C}-\mathrm{Pd}, \mathrm{C}_{6} \mathrm{H}_{3}\right)$, $135.4\left(\mathrm{C}-\mathrm{Cl}, \mathrm{C}_{6} \mathrm{H}_{3}\right), 133.7\left(\mathrm{CH}, \mathrm{C}_{6} \mathrm{H}_{3}\right), 132.3(=\mathrm{CH}), 131.9\left(\mathrm{C}_{\mathrm{p}}, \mathrm{C}_{6} \mathrm{H}_{5}\right)$, $130.7(=\mathrm{C}), 130.0\left(\mathrm{CH}, \mathrm{C}_{6} \mathrm{H}_{3}\right), 129.8\left(\mathrm{C}_{0}, \mathrm{C}_{6} \mathrm{H}_{5}\right), 129.6\left(\mathrm{C}, \mathrm{C}_{6} \mathrm{H}_{3}\right), 128.6$ $\left(\mathrm{C}_{\mathrm{m}}, \mathrm{C}_{6} \mathrm{H}_{5}\right), 128.4\left(\mathrm{C}_{\mathrm{i}}, \mathrm{C}_{6} \mathrm{H}_{5}\right), 126.4\left(\mathrm{CH}, \mathrm{C}_{6} \mathrm{H}_{3}\right), 99.7\left(\mathrm{C}_{3} \mathrm{H}, \mathrm{acac}\right), 44.0$ $\left(\mathrm{NCH}_{2},{ }^{\mathrm{n}} \mathrm{Pr}\right), 27.6$ (Me, acac) , $26.2(\mathrm{Me}, \mathrm{acac}), 22.3\left(\mathrm{CH}_{2},{ }^{\mathrm{n}} \mathrm{Pr}\right), 11.1\left(\mathrm{CH}_{3}\right.$, nPr). HRMS $\left(\mathrm{ESI}^{+}\right)[\mathrm{m} / \mathrm{z}]:$ Calc. for $\mathrm{C}_{25} \mathrm{H}_{26} \mathrm{CIN}_{2} \mathrm{O}_{4} \mathrm{Pd}[\mathrm{M}+\mathrm{OMe}]^{+}: 559.0616$, obtained 559.0631

\section{Acknowledgements}

C. H. and E. P. U. thank the COST program under CA15106 grant: $\mathrm{CH}$ Activation in Organic Synthesis (CHAOS). A. I. J., C. C. and E. P. U. thank Ministerio de Economia y Competitividad MINECO (Spain, Project CTQ2013-40855R) and Gobierno de Aragón (Spain, research group: Aminoácidos y Péptidos) for financial support. This work has been partially supported by Rouen University, The Institut National des Sciences Appliquées de Rouen (INSA Rouen), the Centre National de la Recherche Scientifique (CNRS), the Laboratory of Excellence (Labex) SynOrg and the region Normandie.

Keywords: imidazolone $\cdot$ oxazolone $\cdot$ palladium $\cdot \mathrm{C}-\mathrm{H}$ bond activation•fluorescence

[1] B. Valeur, M. N. Berberan-Santos, Molecular Fluorescence, Principles and Applications. 2nd ed. Weinheim, Germany: Wiley-VCH; 2013.
[2] A. Edgar, Luminescent Materials, in: S. Kasap and P. Capper, eds; Springer Handbook of Electronic and Photonic Materials. Springer Handbooks. 2017, Springer, Cham

[3] A. Kitai, Luminescent Materials and Applications. 1st ed. Weinheim, Germany: Wiley-VCH; 2008.

[4] I. S. Kandarakis, J. Luminescence, 2016, 169, 553-558.

[5] C. Ronda, Progress in Electromagnetics Research, 2014, 147, 81-93

[6] Luminescence Applied in Sensor Science, L. Prodi, M. Montalti, N. Zaccheroni, Top. Curr. Chem. 2011, 300, 1-217.

[7] C. Feldmann, T. Jüstel, C. R. Ronda, P. J. Schmidt, Adv. Func. Mater. 2003, 13, 511-516

[8] A. Acharya, A. M. Bogdanov, B. L. Grigorenko, K. B. Bravaya, A. V. Nemukhin, K. A. Lukyanov, A. I. Krylov, Chem. Rev. 2017, 117, 758-795.

[9] K. M. Dean, A. E. Palmer, Nat. Chem. Biol. 2014, 10, 512-523.

[10] Y. Ohba, Y. Fujioka, S. Nakada, M. Tsuda, Progress in Molecular Biology and Translational Science, 2013, 113, 313-348.

[11] E. A. Rodriguez, R. E. Campbell, J. Y. Lin, M. Z. Lin, A. Miyawaki, A. E. Palmer, X. Shu, J. Zhang, R. Y. Tsien, Trends in Biochemical Sciences 2017, 42, 111-129.

[12] L. D. Lavis, Biochemistry 2017, 56, 5165-5170.

[13] D. M. Chudakov, M. V. Matz, S. Lukyanov, K. A. Lukyanov, Physiol. Rev. 2010, 90, 1103-1163.

[14] R. N. Day, M. W. Davidson, Chem. Soc. Rev. 2009, 38, 2887-2921.

[15] M. Zimmer, Chem. Soc. Rev. 2009, 38, 2823-2832.

[16] O. Shimomura, Angew. Chem. Int. Ed. 2009, 48, 5590-5602.

[17] M. Chalfie, Angew. Chem. Int. Ed. 2009, 48, 5603-5611.

[18] R. Y. Tsien, Angew. Chem. Int. Ed .2009, 48, 5612-5626.

[19] A. Miyawaki, T. Nagai, H. Mizuno, Adv. Biochem. Eng. Biotechnol. 2005 95, 1-15.

[20] R. Y. Tsien, Annu. Rev. Biochem. 1998, 67, 509-544.

[21] T. Misteli, D. L. Spector, Nat. Biotechnol. 1997, 15, 961-964.

[22] G. J. Palm, A. Zdanov, G. A. Gaitanaris, R. Stauber, G. N. Pavlakis, A Wlodawer, Nat. Struct. Biol. 1997, 4, 361-365.

[23] R. Heim, D. C. Prasher, R. Y. Tsien, Proc. Natl. Acad. Sci. USA, 1994 91, 12501-12504

[24] M. Muselli, C. Baudequin, C. Hoarau, L. Bischoff, Chem. Commun. 2015 51, 745-748.

[25] M. Muselli, C. Baudequin, C. Perrio, C. Hoarau, L. Bischoff, Chem. Eur J. 2016, 22, 5520-5524.

[26] M. Muselli, L. Colombeau, J. Hédouin, C. Hoarau, L. Bischoff, Synlett, 2016, 27, 2819-2825.

[27] J. Plöchl, Chem. Ber., 1883, 16, 2815-2825

[28] J. Plöchl, Chem. Ber., 1884, 17, 1623-1624.

[29] E. Erlenmeyer, Justus Liebigs Annalen der Chemie, 1893, 275, 1-8.

[30] H. E. Carter, Org. React.,1946, 3, 198-239.

[31] R. Filler, Advances in Heterocyclic Chemistry, A. R. Katrizky, Editor Academic Press, New York, 1954, chapter 4, p. 75.

[32] Y. S. Rao and R. Filler, Synthesis, 1975, 12, 749-764.

[33] C. Cativiela, M. D. Díaz de Villegas and E. Meléndez, J. Heterocycl. Chem., 1985, 22, 1655-1657.

[34] F. M. Bautista, J. M. Campelo, A. García, D. Luna, J. M. Marinas and A A. Romero, J. Chem. Soc., Perkin Trans 2, 2002, 227-234.

[35] C. E. Augelli-Szafran, A. T. Sakkab and T. Yasunaga, U.S. Pat. Appl. Publ. 2004, US2004180943 A1 20040916

[36] T. Cleary, J. Brice, N. Kennedy and F. Chávez, Tetrahedron Lett. 2010 51, 625-628.

[37] I. Arenal, M. Bernabe and E. Fernández-Alvarez, Anales de Química, Serie C: Química Orgánica y Bioquímica 1981, 77, 56-62.

[38] M. A. Mesaik, S. Rahat, K. M. Khan, Z. Ullah, M. I. Choudary, S. Murad Z. Ismail, A. U. Rahman and A. Ahmad, Bioorg. Med. Chem. 2004, 12, 2049-2057.

[39] R. M. Herbst and D. Sherman, Org. Synth., 1942, 2, 1

[40] T. G. Barros, S. Pinheiro, J. S. Williamson, A. Tanuri, M. Gomes Jr, H. S. Pereira, R. M. Brindeiro, J. B. A. Neto, O. A. C. Antunes, E. M. F. Muri, Amino Acids 2010, 38, 701-709.

[41] R. Saito, M. Hoshi, A. Kato, C. Ishikawa and T. Komatsu, Eur. J. Med. Chem. 2017, 125, 965-974. 
[42] M. B. Siddesh, B. Padmashali, K. S. Thriveni and R. J. Shruthi, Heterocycl. Lett. 2017, 7, 835-840.

[43] K. Y. Chen, Y. M. Cheng, C. H. Lai, C. C. Hsu, M. L. Ho, G. H. Lee and P. T. Chou, J. Am. Chem. Soc. 2007, 129, 4534-4535.

[44] K. M. Khan, U. R. Mughal, M. A. Lodhi and M. I. Choudhary, Lett. Drug. Des. Discov. 2008, 5, 52-56.

[45] C. A. B. Rodrigues, I. F. A. Mariz, E. M. S. Maçôas, C. A. M. Afonso, J. M. G. Martinho, Dyes and Pigments 2012, 95, 713-722.

[46] C. A. B. Rodrigues, I. F. A. Mariz, E. M. S. Maçôas, C. A. M. Afonso, J. M. G. Martinho, Dyes and Pigments 2013, 99, 642-652.

[47] Y. L. N. Murthy, K. P. Suhasini, V. Veeraiah, G. Umesh, K. B. Manjunatha, V. Christopher, Dyes and Pigments 2013, 99, 713-719.

[48] C. García-Iriepa, M. Marazzi, L. M. Frutos, D. Sampedro, RSC Adv. 2013, 3, 6241-6266

[49] M. Blanco-Lomas, P. J. Campos, D. Sampedro, Org. Lett. 2012, 14, 4334-4337.

[50] M. Blanco-Lomas, P. J. Campos, D. Sampedro, Eur. J. Org. Chem. 2012, 6328-6334.

[51] I. Funes-Ardoiz, M. Blanco-Lomas, P. J. Campos, D. Sampedro, Tetrahedron 2013, 69, 9766-9771.

[52] Q. Liu, N. Li, Y. Yuan, H. Lu, X. Wu, C. Zhou, M. He, H. Su, M. Zhang, J. Wang, B. Wang, Y. Wang, D. Ma, Y. Ye, H.-C. Weiss, E. R. F. Gesing J. Liao, M.-W. Wang, J. Med. Chem. 2012, 55, 250-267.

[53] E. Serrano, A. Juan, A. García-Montero, T. Soler, F. Jiménez-Márquez, C. Cativiela, M. V. Gómez, E. P. Urriolabeitia, Chem. Eur. J. 2016, 22 144-152.

[54] A. García-Montero, A. M. Rodríguez, A. Juan, A. H. Velders, A. Denisi, G. Jiménez-Osés, E. Gómez-Bengoa, C. Cativiela, M. V. Gómez, E. P Urriolabeitia, ACS Sustainable Chem. Eng. 2017, 5, 8370-8381.

[55] P. E. Ivashkin, I. V. Yampolsky, K. A. Lukyanov, Russ. J. Bioorg. Chem. 2009, 35, 652-669.

[56] A. Follenius-Wund, M. Bourotte, M. Schmitt, F. lyice, H. Lami, J. J. Bourguignon, J. Haiech, C. Pigault, Biophys. J. 2003, 85, 1839-1850.

[57] B. K. Rajbongshi, P. Sen, G. Ramanathan, Chem. Phys. Lett. 2010, 494, 295-300.

[58] M. E. Martin, F. Negri, M. Olivucci, J. Am. Chem. Soc. 2004, 126, $5452-$ 5464.

[59] P. Altoe, F. Bernardi, M. Garavelli, G. Orlandi, F. Negri, J. Am. Chem. Soc. 2005, 127, 3952-3963.

[60] C. M. Megley, L. A. Dickson, S. L. Maddalo, G. J. Chandler, M. Zimmer J. Phys. Chem. B 2009, 113, 302-308.

[61] L. Wu, K. Burgess, J. Am. Chem. Soc. 2008, 130, 4089-4096.

[62] M. S. Baranov, K. A. Lukyanov, A. O. Borissova, J. Shamir, D. Kosenkov, L. V. Splichenko, L. M. Tolbert, I. V. Yampolsky, K. M. Solntsev, J. Am. Chem. Soc. 2012, 134, 6025-6032.

[63] M. S. Baranov, K. M. Solntsev, N. S. Baleeva, A. S. Mishin, S. A. Lukyanov, K. A. Lukyanov, I. V. Yampolsky, Chem. Eur. J. 2014, 20 13234-13241.

[64] N. S. Baleeva, K. A. Myannik, I. V. Yampolsky, M. S. Baranov, Eur. J. Org. Chem. 2015, 5716-5721.

[65] N. S. Baleeva, A. S. Tsarkova, M. S. Baranov, Tetrahedron Lett. 2016, 57, 3043-3045.

[66] I. V. Yampolsky, K.A. Lukyanov, M. S. Baranov, Boron-containing 5arylidene-3,5-dihydro-4H-imidazol-4-ones; patent WO2014/031021 A1.

[67] S. Huo, J. Carroll, D. A. K. Vezzu, Asian J. Org. Chem. 2015, 4, 1210 1245.

[68] L. Ravotto, P. Ceroni, Coord. Chem. Rev. 2017, 346, 62-76.

[69] C. Bronner, O. S. Wenger, Dalton Trans. 2011, 40, 12409-12420.

[70] J. Kalinowski, V. Fattori, M. Cocchi, J. A. G. Williams, Coord. Chem. Rev. 2011, 255, 2401-2425

[71] Y. Chi, P. T. Chou, Chem. Soc. Rev. 2010, 39, 638-655.

[72] R. Kumar, C. Nevado, Angew. Chem. Int. Ed. 2017, 56, 1994-2015.

[73] D. L. Ma, S. Lin, W. Wang, C. Yang, C. H. Leung, Chem Sci. 2017, 8, 878-889.

[74] V. W. W. Yam, V. K. M. Au, S. Y. L. Leung, Chem. Rev. 2015, 115, 75897728.
[75] L. Bischoff, C. Baudequin, C. Hoarau, E. P. Urriolabeitia, Adv. Organomet. Chem. 2018, DOI: 10.1016/bs.adomc.2018.03.001.

[76] H. Yersin, A. F. Rausch, R. Czerwieniec, T. Hofbeck, T. Fischer, Coord. Chem. Rev. 2011, 255, 2622-2652.

[77] M. S. Kwon, Y. Yu, C. Coburn, A. W. Phillips, K. Chung, A. Shanker, J. Jung, G. Kim, K. Pipe, S. R. Forrest, J. H. Youk, J. Gierschner, J. Kim, Nature Comm. 2015, 6, 8947.

[78] M. Albrecht, Chem. Rev. 2010, 110, 576-623.

[79] G.-D. Roiban, E. Serrano, T. Soler, I. Grosu, C. Cativiela, E. P. Urriolabeitia, Chem. Commun. 2009, 4681-4683.

[80] G.-D. Roiban, E. Serrano, T. Soler, G. Aullón, I. Grosu, C. Cativiela, M. Martínez, E. P. Urriolabeitia, Inorg. Chem. 2011, 50, 8132-8143.

[81] G.-D. Roiban, T. Soler, I. Grosu, C. Cativiela, E. P. Urriolabeitia, Inorg. Chim. Acta 2011, 368, 247-251.

[82] G.-D. Roiban, E. Serrano, T. Soler, M. Contel, I. Grosu, C. Cativiela, E. P. Urriolabeitia, Organometallics 2010, 29, 1428-1435.

[83] Z.-Q. Chen, Z.-Q. Bian, C.-H. Huang, Adv. Mater. 2010, 22, 1534-1539. [84] Y. Liu, H. Guo, J. Zhao, Chem. Commun. 2011, 47, 11471-11473.

[85] A. Valore, A. Colombo, C. Dragonetti, S. Righetto, D. Roberto, R. Ugo, F. De Angelis, S. Fantacci, Chem. Commun. 2010, 46, 2414-2416.
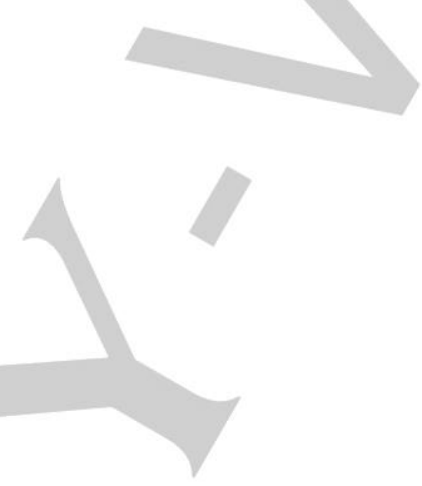
WILEY-VCH

\section{FULL PAPER}

\section{Entry for the Table of Contents}

\section{FULL PAPER}

The orthopalladation of 4-aryliden$5(4 H)$-oxazolones and -imidazolones through $\mathrm{C}-\mathrm{H}$ bond activation is regioselective and gives dimers where only the ortho position of the 4arylidene ring is activated. The carboxylate ligands can be replaced by acetylacetonate, affording rigid neutral mononuclear complexes. The photophysical properties of these rigid mononuclear complexes have been examined and confirm the importance of rigidification of imidazolones.

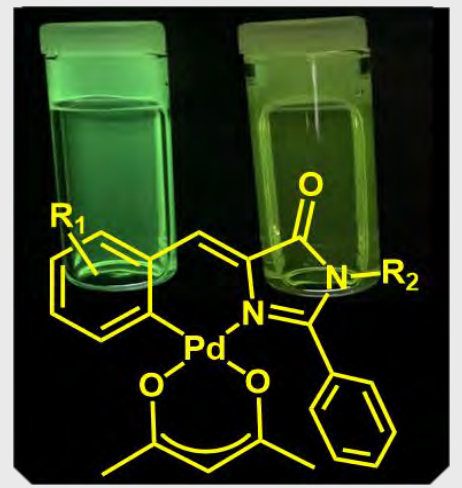

GFP-orthopalladated fluorophores *

Sandra Collado, Alejandro Pueyo, Christine Baudequin, Laurent Bischoff, Ana Isabel Jiménez, Carlos Cativiela*, Christophe Hoarau*, and Esteban P. Urriolabeitia*

Page No. - Page No.

Orthopalladation of GFP-like fluorophores through $\mathrm{C}-\mathrm{H}$ bond activation: scope and photophysical properties 